\title{
Legal Mentality of Diasporas: Experience in Theoretical and Methodological Design
}

\author{
Evgeny A. Apolsky ${ }^{1}$, Alexander Kim², Mamychev Aleksei Yurievich ${ }^{3}$, Mordovtsev Andrei Yurievich ${ }^{3,4,5}$ \& \\ Romanenko Veronika Borisovna ${ }^{1}$ \\ ${ }^{1}$ Rostov Institute (Branch), All-Russian State University of Justice, Rostov-on-Don, Russia \\ ${ }^{2}$ Department of International Relations and Law, Vladivostok State University of Economics and Service, \\ Vladivostok, Russia \\ ${ }^{3}$ Department of Theory and History of Russian and Foreign Law, Vladivostok State University of Economics \\ and Service, Vladivostok, Russia \\ ${ }^{4}$ Department of Theory and History of State and Law, Rostov Institute (Branch), All-Russian State University of \\ Justice, Russia \\ ${ }^{5}$ Department of International Law, Rostov Branch, Russian State University of Justice, Russia \\ Correspondence: Alexander Kim, Department of International Relations and Law, Vladivostok State University \\ of Economics and Service, Vladivostok, Russia. E-mail: kimaa9@gmail.com
}

Received: October 22, $2019 \quad$ Accepted: November 17, $2019 \quad$ Online Published: November 28, 2019

doi:10.5539/jpl.v12n4p99 URL: https://doi.org/10.5539/jpl.v12n4p99

The work is done under financial support of the grant RFBR №17-33-00034 "Legal mentality of provincial communities and diasporas in modern Russia: theoretical and methodological and comparative legal aspect (on the example of the Far East and the Southern Federal District)"

\begin{abstract}
This article presents theoretical and methodical as well as pragmatic basis of the theory of mentality of diasporas and provincial communities which is just taking shape in domestic legal and political knowledge. Great attention is paid, in particular, to legal mentality of diasporas' representatives manifests itself in a different way in the social space of a multinational state. The authors of this work believe that turning to steady in time mental attitudes common for representatives of different diasporas is necessary first of all for forming an adequate political and legal strategy of the national development, for pursuing relevant legal policies in different Russian regions. The contents and peculiarities of the legal mentality of diasporas and provincial communities should be taken into account in the process of defining priorities of reforming the legal and political system, choosing ways and methods of changes in the legal, political and socioeconomic fields. Besides, thorough research of legal mentality of different diasporas will give a chance to find out the ethnocultural component of dynamics in social processes and to assess them (e. g. in the issues of level of riskogenicity and conflictogenicity), to outline possible results and perspectives. The article considers features of legal mentality of the diasporas of the Far Eastern region of Russia as a specific example.
\end{abstract}

Keywords: legal mentality, diaspora, legal culture, legal acculturation, legal marginalization, attitudes, legal assimilation, globalization, legal integration, language, religious outlook

\section{Introduction}

In the context of the development of the modern humanitarian and social cognition it is hardly worth arguing about the fact that introducing the notion "mentality" in the scientific vocabulary creates important methodological background for a new historical and social understanding, gives a possibility to use it in two ways: firstly, the mechanism of typical behavior and actions can be reconstructed through a special procedure of identification and "substitution" for world outlook, thinking, action-schemes, emotional sphere of a representative of one single society of a certain epoch to the place of a "personage" from a different society, of a different civilization type belonging to the same or to a different epoch; secondly, it is possible to recreate those types of behavior which were not manifested (or weakly expressed) in the texts as conceivable but not realized 
by individuals for different reasons actions.

If to summarize the main theoretical and methodological provisions, existing in history of science and in modern humanitarian theories, in social, political and legal studies, the following defining heuristic possibilities of the theory of mentality can be distinguished:

- firstly, mentality is taken as the contents (image, representation, concept), the totality of "living" stereotypes, attitudes, and as a process (dynamic characteristics of mentality and its manifestations);

- secondly, mentality is a stable mood of the inner world of individuals rallying them into national (if to consider wider - civilizational) communities, small social (ethnic, etc.) groups, professional corporations and so on, a set of attitudes and predispositions of subjects to a certain type of thinking and action;

- thirdly, mentality describes human activity only in the context of a certain historical-civilizational, national material and when eliminating the latter it either becomes one more designation of consciousness (public consciousness), psyche or is just included in everyday use;

- fourthly, mentality is "double digit", on the one hand, it is the result of culture and traditions, on the other hand, it is, by itself, a deep source of development of the latter, it defines the vector of culture-civilizational dynamics;

- fifthly, being a form of expressions of group consciousness mentality allows to understand the peculiarity of perception and evaluation of a particular social phenomenon or process by various social groups, to explain the character and specific behavior of representatives of these groups, society as a whole in a variety of (normal or crisis) situations;

- at sixth, mentality is an emotional-value and at the same time conscious-volitional cut (measurement) of the life of any society;

- seventh, mental cultural symbolic structures acting as the "objective" foundations of society determine and mark various social phenomena (legal, political, ethical, etc.) ${ }^{1}$.

Summarizing all this it is possible to say that legal mentality is an inalienable, deep-seated and stable component of the national political and legal reality, significant aspect of its consideration and criterion for assessing possible development prospects. The legal (political-legal) mentality is the totality (system) of legal archetypes and representations, stable, familiar images, forms and styles of legal thinking which have their own content in different societies, ethnic groups, types of civilizations, etc., but always underlie the perception of the components of national statehood (political institutions and structures, national and confessional relations, etc.), determine the specifics of the legal behavior of the individual, of various social, professional groups, state bodies and officials ${ }^{2}$.

\section{Research Methodology}

As the methodological principles on which the study of the legal mentality of provincial communities and diasporas is based, the following can be distinguished:

1) the principle of complementarity in understanding the specific behavior of individuals (representatives of different ethnic diasporas) and their groups (diasporas in general) in the legal sphere, when on the one hand, the existing legal and political institutions, structures and mechanisms largely determine human activity, its character and orientation and on the other hand, the effectiveness and sustainability of the legal and political components of national statehood are determined by the "subjective factor";

2) the principle of "understanding interpretation", i.e. the concept of the legal mentality of diasporas is built by methods of understanding and explanation, which generally corresponds to the heuristic settings of post-non-classical (understanding) science. It was this approach that made it possible to examine the sphere of legal everyday life of diasporas, the features of their legal and political activity, identify the factors of sustainable development of domestic statehood and civil society institutions, evaluate the criteria for determining the effectiveness of regional and federal legislation in its legitimate dimension;

3) ethno-cultural conventionality means that the value-normative systems operating in society have a concrete historical and socio-communicative nature. Moreover, the knowledge of the latter is determined by the

\footnotetext{
${ }^{1}$ Goffman A.B. (2015).Tradition, solidarity and sociological theory. Selected Texts. Moscow: New Chronograph; Mordovtsev A., Zhinkin S., Mamychev A., Yakovyuk A., Shestopal S. (2017), Legal Mentality in National Cultural Space: Characteristics of the ERA of Change (Church Schism of the 17th Century). Man In India. Vol. 97. № 23. pp. 295-309; Lotman Yu. M. (2002). History and typology of Russian culture. St. Petersburg: "Art-St. Petersburg”,

${ }^{2}$ Mordovtsev A.Yu., Popov V.V. (2007). Russian legal mentality. Rostov n / a: Publishing house of SFU, p. 64.
} 
ethno-national, sociocultural and historical context, any legal phenomenon or process is theoretically and philosophically loaded and caused by sociocultural factors and dominants;

4) integrity is a methodological principle of systemic and organic unity, interaction and interdependence of all elements of the socio-legal and ethno-national life of the society;

5) objectivity as the methodological principle of the present study involves orientation to the reconstruction of existing ideas and characteristics of the legal worldview of the diasporas, independent of the will and consciousness of individual individuals;

6) reliability focuses on the agreement of the findings and provisions with the available theoretical and methodological achievements of legal science, analytical and empirical data, as well as the right-cultural and ethno-legal context;

7) instrumental legal realism means knowledge of sociocultural factors and ethno-legal dominants necessary not only for understanding the law and legal worldview of the peoples of Russia, but also for managing real-life social and legal phenomena and processes.

Among foreign and Russian researchers in the sphere of development of the concept of national mentality and the methodology of its study the works of E. A. Anufriev, M. M. Bakhtin, N. I. Biryukov, G. Butulya, P. S. Gurevich, G. G. Diligensky, V. Diltey, P. Dintselbakher, A. Inkels, J. Karbonye, D. Levinson, L. V. Lesnoy, B. V. Markov, I. V. Mostovaya, A. S. Panarin, I. K. Pantin, V. M. Rosin, G. Simmon, N. E. Tikhonova, M. Karbonye, G. Hofsted, R. Emerson and others present the greatest interest ${ }^{3}$.

Issues of national character, sociocultural codes and traditions of a particular people and diasporas, their characteristics and also the role of the latter in the maintaining and reproducing sustainable social communities acted as one of the priority in the humanities in the XVIII - XX centuries, formed a whole theoretical and methodological tradition and guidelines for research ${ }^{4}$. Separately, the works of I.A. Ilyin, B. A. Kistikovsky, K. V Chistov should be mentioned ${ }^{5}$. In the socio-psychological context, great attention was paid to the problems posed by Z. Barbu, I. G. Dubovy, B. A. Dushkova, V. Vundt, G. Lebon, R. Mandru, V. A. Shkuratov, E. Fromm, K. G. Yung and others ${ }^{6}$. Interesting and valuable heuristic developments in the field of ethno-national worldview were obtained by experts in the field of cultural studies and legal (political) anthropology (I. Y. Bakhoven, A. Garapon, L. Levi-Bruhl, K. Levi-Strauss, B. Malinovsky, N. Rulan, G. Dj. Samner-Man and others) ${ }^{7}$. This tradition in legal, political and anthropological studies continues today, representing a body of fairly significant and

\footnotetext{
${ }^{3}$ Bakhtin M.M. (1997). Collected works in 7 volumes. V. 5. Moscow: Russian dictionaries; Biryukov N.I., Sergeev V.M. (1997). "Unity" as a paradigm of political consciousness. Political studies. No. 3. pp. 65-73; Mostovaya I.V., Skorik A.P. (1995). Archetypes and landmarks of the Russian mentality. Policy. No. 4. pp. 69-76; Gurvich G.D. (2004). Philosophy and Sociology of Law: Selected Works / Transl. M.V. Antonova, L.V. Voronina. - SPb.: Publishing House of St. Petersburg State University, Publishing House of the Law Faculty, Carbonier J. (1980). Legal Sociology. Moscow: Progress, Rozin V.M. (2018). History and methodology of legal science. Legal thinking. Moscow.: Yurayt, ${ }^{4}$ Alekseev N.N. (2001). The idea of the state. Moscow: Agraf, Berdyaev N. A. (1997). Russian idea: The main problems of Russian thought of the XIX century and the beginning of the XX century; The destiny of Russia. Moscow: Svarog and K, Gurevich A.Ya. (1988). The study of mentalities. Soviet ethnography. No. 6. pp. 16-25; Gurevich A.Ya. (1990). The Medieval World: A Culture of the Silent Majority. Moscow: Nauka; Velichko A.M. (2002). Moral and national foundations of law: Collection of articles on the philosophy and history of law. SPb.: Publishing House of St. Petersburg State University; Vysheslavtsev B.P. (1995). Russian national character. Questions of philosophy. No. 6. [electronic resource]. Access mode: http://www.kph.npu.edu.ua/!e-book/clasik/data/vopros/11.html; Gachev G.D. (1995). National images of the world. Cosmo-Psycho-Logos. Moscow: Progress,

${ }^{5}$ Chistov K.V. (2011). Russian folk utopia (genesis and functions of socio-utopian legends). St. Petersburg: Dmitry Bulanin; Ilyin I.A. (2011) The path of spiritual renewal / Comp., Ed. foreword ed. O.A. Platonov. Moscow: Institute of Russian Civilization, Kistyakovsky B.A. (1916). Social sciences and law. Essay on the methodology of social sciences and the general theory of law. Moscow : Edition of M. and S. Sabashnikovs; Petrazhitsky L.I. (2010). Theory and politics of law. Selected Works. St. Petersburg: University Publishing Consortium“" Legal Book "; Novgorodtsev P.I. (1999). Historical School of Lawyers. SPb.: Publishing House of St. Petersburg State University; Danilevsky N.Ya. (2008). Russia and Europe: A look at the cultural and political relations of the Slavic world towards the German-Romanesque. Moscow: Institute of Russian Civilization; Markaryan E.S. (1981). Nodal problems of the theory of cultural tradition. Soviet Ethnography. pp. 78-96;

${ }^{6}$ Gerasimov I.V. (2004). Russian mentality and modernization. Social sciences and the present. No. 4. pp. 33-45; Jung K.G. (1991). Archetype and symbol. Moscow : Renaissance; Fromm E. (2009). Escape from freedom. Moscow : AST Moscow Publishing House; Lebon G. (2011). Psychology of peoples and masses. Moscow : Academic project;

${ }^{7}$ Historiogenesis and the state of the Russian mentality / Otv. ed. V.A. Koltsova, E.V. Kharitonova. (2015). Moscow: Publishing House "Institute of Psychology RAS"; Rulan N. (1999). Legal anthropology. Moscow: Norma; Levy-Bruhl L. (2002). Primitive mentality. St. Petersburg: European House; Levy-Strauss K. (1985). Structural Anthropology. Moscow: Nauka, GRVL; Malinovsky B. (2005). Scientific Theory of Culture. Moscow : OGI;
} 
fundamental research ${ }^{8}$.

From a historical and cultural perspective, aspects that were very important for understanding the specifics of the Russian mentality were identified by N.I. Kostomarov in his work "Customs and mores of the peoples of the Russian state" which includes, in particular, such sections as "Family manners", "Housekeeping order", "Amusement, games, fun", "Villages and villages", "Beliefs" and others ${ }^{9}$. Approximately the same aspects of Russian life, but from the perspective of a foreigner, is considered by J. Fletcher, whose observations are heuristically valuable for conducting a comparative analysis of the content and manifestations of the Russian and Western European mentality in domestic and foreign legal and political life ${ }^{10}$. An original and one-of-a-kind study of the mentality of diasporas was carried out by Z.I. Levin, though, he limited himself to studying a number of staged aspects of this complex problem ${ }^{11}$.

\section{Main Part}

There are currently no works devoted to a comprehensive and comprehensive study of the nature of the legal mentality of provincial communities and diasporas in Russia, their relationship with the general legal characteristics of Russian society in modern domestic and foreign scientific knowledge. In this regard, of course, there is no heuristically verified methodology for a comprehensive study of this phenomenon.

Though, to draw up a general methodological context and form an integrated approach to solving the main aspects of the stated problems, the following guidelines should be taken into account:

- Religious worldview and its role in the life and culture of a particular ethnos;

- The relations "Aliens" and "Own" as a guideline for the formation of legal relations between representatives of diasporas, local provincial communities and other subjects of the legal and political life of modern Russia;

- The value of the family (clan) and its interests, the level of satisfaction of representatives of national diasporas with the legal fixation of their inherent interests and values;

- The traditional attitude to state and other authorities ("distance of power");

- The level and nature of the cohesion of the representatives of the diasporas, the ability to withstand current legal, political and economic "challenges", various kinds of crisis phenomena;

- Factors of integration or disintegration of diasporas into modern domestic social and legal space;

- Attitude to work (including collective labor) and to various forms of ownership, methods of their legal fixation;

- Attitude to the current legislation ("Law" - "Custom" - "Traditions").

- The dominant type of lawful behavior (conformist, marginal, etc.), arising as a result of the refraction of the social and legal space surrounding the diasporas and local provincial communities, in their stable, transmitted from generation to generation attitude, ideas about the order and justice, honor and dignity of the individual.

- The specifics of gender and age interaction within the diasporas (habitual status of a man, woman, child, old man, husband, wife, father, mother).

- The level of isolationism of the diaspora (high, medium, low), its determining parameters.

Turning to the question of the theoretical and methodological foundations of the study of the legal mentality of diasporas and provincial communities, allowing to reconstruct and "decipher" this part of the national legal space, a number of fundamental provisions should be highlighted.

1) The legal mentality of diasporas (provincial communities) is a deep and sustainable component of their social

\footnotetext{
${ }^{8}$ Malinovsky B. (1998). Magic, science and religion. Moscow: Refl beech; Mordovtsev A.Yu. (2003). The reality of the legal world in the space of national culture: questions of theory and methodology. Philosophy of Law. No. 2. pp. 69-75; Nevvazhay I.D. (2000). Types of legal culture and forms of justice. Jurisprudence. No. 2. pp. 22-31; Nersesyants V.S. (1999). Legal anthropology as a science and academic discipline. Rulan N. Legal anthropology. Moscow : Publishing. Norma; Ovchinnikov A.I. (2002). Legal thinking in the hermeneutic paradigm. Rostov n / a; Okara A.N. (1999). Legal awareness is the central category of philosophy of law I.A. Ilyina. State and Law. No. 6. pp. 121-128; Oly P.A., Romashov R.A. (2002). Nation (genesis of the concept and issues of legal personality). St. Petersburg: Logos;

${ }^{9}$ Pantin I.K. (1994). National mentality and history of Russia. Russian mentality (materials of the "round table"). Questions of philosophy. No. 1. pp. 34-44

${ }^{10}$ Kostomarov N.I. (2018). Customs and manners of the peoples of the Russian state. Moscow: Publishing AST; Fletcher J. About the Russian state. Driving through Muscoviya (Russia XVI - XVII centuries through the eyes of diplomats). Moscow : Intern. Relations, 1991. [Electronic Resource]. Access mode: http://az.lib.ru/f/fletcher_d/text_1591_of_the_russe_common_wealth.shtml;

${ }^{11}$ Russia of the 16th century The memories of foreigners. (2018). Smolensk: Rusich;
} 
and legal life, the basis for the interaction of their representatives between themselves and other population of the state, a significant aspect of considering the specifics of the basic legal values inherent in the diaspora or provincial culture, an important criterion for assessing the prospects for the integration and development of ethnic groups and communities in a foreign cultural (host) legal environment. In the essential dimension, legal (or, more broadly, political and legal) mentality is a combination of legal archetypes and ideas, familiar images, forms and styles of legal thinking which are inevitably formed in different diasporas, ethnic groups, provincial communities, have their own content, are combined in different ways, but they always underlie the perception of the components of the national legal system (legal institutions and norms), interethnic and confessional relations, etc.), determine the prevailing types and specifics of the legal behavior of individuals belonging to specific diasporas, provincial communities, the nature of their interaction between themselves and other("Alien") subjects of law;

2) The conceptualization of the legal mentality of the diasporas and provincial communities, their consideration in the context of the scientific (socio-philosophical, socio-psychological and socio-legal) positions taking place in Russian and foreign literature made it possible to draw a conclusion about the obvious heuristic unproductiveness a binary model of legal ethnic legal mentality emerged at the beginning of the 20th century, which implies a distinction between conscious and unconscious elements, the identification of which often depends on the situation and the depth of reflection of the subjects. The retreat from traditional (overly psychologized) views in favor of a different type of rationality, the identification of the sociocultural nature of the diaspora mentality, involves the study of its architectonics, that is the complex of mutually penetrating structures: the legal paradigm, the style of legal thinking and the social (legal) interaction of entities that is expressed in different types of their legal (legal or illegal) behavior. With this approach (and this is especially important in practical terms), the legal mentality of diasporas and provincial communities is a kind of matrix for typing the legal behavior of their representatives;

3) The legal manifestations of the representatives of the diasporas (for example, attitudes, stereotypes, attitudes) are the basis for their understanding and assessment of Russian statehood in general, taking place in the organization of power relations and institutions, national legal policy in general, but most importantly, they affect the political activity and legal behavior of the population countries. It is this characteristic of the legal mentality of the diasporas that allows us to distinguish its main functions: cognitive-transformative, evaluative, prognostic. Primary (experimental) sociological studies conducted in the Southern Federal District in Primorye Region (in the form of questioning of the region's population by quota sampling, and in the form of an expert survey among representatives of state and municipal authorities, public organizations and movements, political parties, ethnic diasporas, etc.) allowed us to determine the fundamental differences in the attitude to the power structures operating in these regions (state and municipal) of the diasporas of the South of Russia (Armenian, Tajik, Jewish, etc.) and the diasporas of the Far East (Korean, Chinese, etc.), which was reflected the term "distance of power" formulated in the domestic social and legal knowledge for the first time.

The concept of "distance of power" can be defined as the degree to which citizens not endowed with power admit (understand, feel) and accept that power is distributed unfairly and enforces decisions that for the most part infringe on the interests of a number of social strata, expressed (materializing) in the system of relevant power practices.

Questioning and interviewing (as methods of the sociology of law) of representatives of the South Russian diasporas showed that they are less acutely aware of all sorts of deformations of modern power relations, consider a number of them (for example, the manifestation of kinship in the distribution of various state or municipal posts, corruption, etc.) rather than classical Far Eastern diasporas, representatives of which are intolerant of various kinds of arbitrary arbitrariness to a greater extent. Approximately the same kind of results were obtained with regard to provincial communities, residents of municipalities of the Rostov Region, Stavropol Territory, on the one hand, and provincial communities of the Far East, which are very sensitive to any kind of deformation of power relations both in Russia as a whole and in Primorye Region;

4) When conducting a comprehensive, systematic study of legal mentality, the great importance of such a legal element as attitude was found, the meaning and sense of this category are still far from their unambiguous understanding in Russian social, including legal knowledge (for example, to study the specifics of the national legal culture, legal consciousness, legal mentality, etc.).

The concept of "attitude" was first introduced in 1918 by sociologists W. Thomas and F. Znanietsky when studying the problems of adaptation of the Polish diasporas consisting of peasants who emigrated to the USA. In their work "The Polish Peasant in Europe and America," they defined attitude as "a state of consciousness of the 
individual relative to a certain social value, the person's experience of the sense of this value"12. In our study, we presented the author's understanding of the "legal attitude", which functions both as an element of the structure of the legal mentality and legal consciousness of the individual (representative of the diaspora or local provincial community), and as an element of the legal mentality of the diaspora as a whole (which, of course, is closely linked, but it does not always coincide completely).

Legal attitude is a state of psychological readiness based on the existing personal or community legal experience, the content of legal consciousness and the logic of legal thinking, which has a direct influence on the individual's reactions regarding various kinds of legal conflicts, legal situations, legal values, assessing the effectiveness of law enforcement, executive or legislative institutions of state power, municipal structures directly or indirectly affecting its interests ${ }^{13}$.

Legal attitudes should be considered in the context of the level of isolationism inherent in diasporas in a particular historical period in the host political, legal, and sociocultural environment and should be correlated with a changing (or, conversely, persisting) scale of legal values and norms established as a result of customs, business practices and traditions and norms of (legal) behavior ${ }^{14}$.

5) In addition to legal attitudes, language is more than a significant factor in the formation of the legal subculture of ethnic diasporas. The process of right-cultural adaptation among representatives of the diasporas who have mastered the language of the host society and state is not only faster, but also at a higher quality level, it is more effective (in terms of mastering the current legislation of the host state, obtaining primary legal knowledge, skills, experience, etc.) in comparison to the diasporas most of whose members are, in point of fact, "without language".

The latter is to a greater extent characteristic, for example, of the Chinese and Korean diasporas in the Far East (they are constantly replenished with new members who, as a rule, do not speak Russian), which affects the low rate of their sociocultural and political and legal adaptation in the Russian state space, but significantly increases their level of cohesion (ethnical solidarity) which they see as an important factor of "survival" in a foreign, foreign, and foreign culture ${ }^{15}$. It is also clear that the "lack of language" of the diasporas only strengthens their isolationism, when the legal norms and institutions that are in force in the host state are not perceived and even rejected by the diasporas, their representatives are extremely wary of the state's legal regulation mechanism, they don't trust it. Diasporas in the south of Russia most often speak Russian properly (for the most part) and, therefore, the subcultures they have formed are more susceptible to the legal space of Russia ${ }^{16}$. Using the methods of legal hermeneutics and the comparative legal method allow us to obtain results of high heuristic significance, which also positively influences their practical effectiveness and emphasizes the high degree of scientific novelty ${ }^{17}$.

6) In 2018, in the course of sociological research in the Primorye Territory and the Southern Federal District, the assertion that "in an industrial society, the cultural distance between the diaspora and the indigenous population is rapidly shrinking" was critically evaluated. This situation is not universal and cannot be extended to different types of diasporas living in different parts of a multinational state. In particular, for representatives of ethnic diasporas living in capital cities or megalopolises, this situation is verifiable, but the use of an arsenal of sociological methods to understand the specifics of the content of the legal mentality of diasporas in Russian regions and provincial entities convinces of the secondary nature of economic factors, as the level of isolation of

\footnotetext{
${ }^{12}$ Levin Z.I. (2001). The mentality of the diaspora (systemic and sociocultural analysis). Moscow : Institute of Oriental Studies, Russian Academy of Sciences, Kraft +; Thomas W., Znaniecki F. (1927). The Polish Peasant in Europe and America. Vol. 1. Second edition. N.Y.;

${ }^{13}$ Seregin A., Mamychev A., Mordovtseva T., Mordovtsev A., Plotnikov A. (2018). Political-legal and social-cultural regularities of the medieval polish monarchy development. Orbis. (Revista Cientifica Electrónica de Ciencias Humanas / Scientific e-journal of Human Sciences). № 14. pp. 120-129;

${ }^{14}$ Ovchinnikov A.I., Mamychev A.Yu., Manastyrsky A.V., Tyurin M.E. (2009). Legal archetypes in the legal policy of Russia. Rostov n / a,

${ }^{15}$ Mamychev A.Yu., Ovchinnikov A.I., Tyurin M.G. (2012). Conceptual and legal interpretations of the archetype. Paradigm bases and strategies for transforming the public administration system and providing public law services to the population in modern Russia. - Taganrog: IP Kravtsov V.A pp. 84-89.

${ }^{16}$ Kondakov I.V.. Sokolov KB, Khrenov N.A. (2011). Civilizational Identity in the Transitional Epoch: Cultural, Sociological and Art History Aspects. Moscow : Progress-Tradition; Pelipenko A.A., Yakovenko I.G. (1998). Culture as a system. Moscow: Publishing House "Languages of Russian Culture";

${ }^{17}$ Shatsky E. (1990).Utopia and Tradition. Moscow : Progress; Ovchinnikov A.I. (2004). Legal hermeneutics as a legal understanding. Jurisprudence. - S.-Pb .: Publishing house S.-Petersburg. University, No. 4.pp. 160-169
} 
diasporas, their distance from the legal culture, legal values of the indigenous population remains high ${ }^{18}$.

The latter, first of all, should be attributed to the Eastern or Asian diasporas, whose representatives seek to preserve the conservative legal foundation in their life and very slowly master the unusual political and legal space. The latter is primarily attributed to women and the elderly in the diasporas, which, due to their gender and age characteristics and social roles, their traditional status ("guardians of ethnocultural continuity and family traditional legal values") are even more slowly adapting to the legal and political life of the host society. Thus, turning to the study of the legal mentality of different diasporas allows introducing into the scientific circulation of modern jurisprudence (sociology of law, philosophy of law, criminology, etc.) the category "rate of legal adaptation".

\section{Conclusions}

A systematic and sociocultural analysis of the provincial diasporas in southern Russia (Armenian, Jewish, Tajik, etc.) and the diasporas of the Far East allows us to identify several stages of their adaptation in the legal space of the host society. Here you should pay attention to the following stages: legal acculturation, legal marginalization and legal (partial) assimilation. The attitude of the diaspora representatives to the legal institutions and values of the host society at each of these stages differs significantly, as does their legal (and political) experience living in the space of the host state.

The primary sociological and legal study of different diasporas allowed us to formulate a number of conclusions that are important for further research on the specifics of their legal mentality:

a) at the stage of legal acculturation, all legal information coming from the host society is perceived and evaluated by representatives of diasporas exclusively through the prism of ethnic self-awareness ("old"), as a result of which new elements of the legal system of the host society are refracted at the level of legal consciousness and on the level of legal the thinking of diaspora members specific synthesized legal forms, legal guidelines are formed that serve as a kind of basis for the "survival" of ethnic diasporas in legal regulative field of the host society. However, at this stage, the legal knowledge and skills themselves are being accumulated, gradually (in different diasporas at different rates) becoming the basis for the formation of principles and approaches to solving legal problems arising from an individual representative of the diaspora or the diaspora as a whole. Note that at this stage, representatives of the diaspora show a desire to protect their right-cultural (ethnic) identity, to preserve legal identity;

b) legal marginalization is the next stage in the adaptation of diasporas. Most often, it arises at the level of legal mentality, legal consciousness, and legal thinking of migrants (representatives of diasporas) of the third or fourth generation, when ethnic socio-legal (legal) constants related to the perception of the surrounding legal environment are still preserved, but are no longer dominant. At this stage, the majority of young representatives of the diaspora, while preserving their ethnic identity at the household, family level, as carriers of the diaspora language, are already very willing to assimilate legal institutions, the norms of their host society, are included in various kinds of private-legal relations with representatives of the latter.

Often, for example, in the diasporas of southern Russia and even the Far East (though the truth is somewhat rarer here), "Russification" (Russian assimilation) of names and surnames occurs, which is also fixed in the relevant documents (for example, in a passport, birth certificate). Representatives of ethnic diasporas at the stage of legal marginalization seek to improve their social status using legal means, for example, receive education (in the language of the host society), participate in elections, seek various kinds of appearances in the media, create some political movements, parties (of course, within the framework of a democratic political and legal space) capable, in their opinion, of expressing their ethnic political, legal, socio-economic, and religious interests. Thus, the diasporas are already "on the edge" ("marginal") of assimilation into the legal culture of the host society.

c) legal assimilation is the highest level of political and legal adaptation of diasporas in general and their individual representatives. Here, the latter are to greater extent carriers of the legal culture of the host society, and the ethnocultural constants of the legal mentality of the diasporas are minimized. A number of authors (foreign sociologists and anthropologists of law) even write about the possibility of "absolute" legal assimilation of diasporas, which, in essence, is identical to their complete "dissolution" in the legal space of the host society. Legal adaptation leads to legal integration. However, criminological studies (American, German, etc.) show different versions, namely, that the specificity of the legal mentality of representatives of diasporas is preserved

\footnotetext{
${ }^{18}$ Mamychev A., Mordovtsev A., Kalinovsky Y., Khaustova M., Chevychalova Z. (2018). The head of state institute in the mixed and hybrid political system. Orbis. (Revista Cientifica Electrónica de Ciencias Humanas / Scientific e-journal of Human Sciences). No. 14. pp. 130-139.
} 
in the fifth and sixth generation, and therefore there are peculiarities of their legal behavior (for example, the processes of criminalization of legal consciousness go more intensively). Moreover, the studies of the diasporas of the Far East and the south of Russia convince us that globalization factors are a powerful incentive to preserve the legal ethnic culture of diasporas as a factor in ensuring their legal identity and originality in the domestic political and legal space.

\section{Copyrights}

Copyright for this article is retained by the author(s), with first publication rights granted to the journal.

This is an open-access article distributed under the terms and conditions of the Creative Commons Attribution license (http://creativecommons.org/licenses/by/4.0/). 